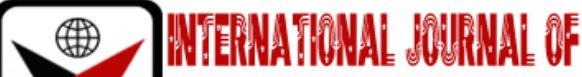

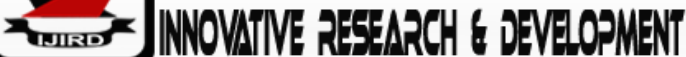

ISSN 2278-0211 (Online)

\section{Evaluation of Cactus (Opuntia Ficus Indica) and Prosopis Juliflora-Based Rations on Performance of Red Masai Weaner Lambs in Kenya}

Margaret Syomiti
Ph.D. Student, Department of Natural Resources Management,
Egerton University, Kenya
Elias Maranga
Associate Professor, Department of Environment and Resources Development (FERD),
Egerton University, Kenya
Gilbert Obwoyere
Associate Professor, Department of Landscape Ecology and Ecosystem Health,
Egerton University, Kenya

\begin{abstract}
:
The purpose of this study was to determine plausible pathways to combat feed scarcity and quality in dry lands using locally available and under-utilized feed resources. Red Maasaiweaner lambs were blocked on the basis of body weight and physiological condition. The treatment diets included pure rations of Cenchrusciliaris hay (control) and proportionally determined combinations of P. juliflorapod meal, spineless (O. ficusindica) Cactus leaf meal and C. ciliaris hay. Analysis of variance (ANOVA) methods were used to isolate significant treatment effects on Cactus (O. ficusindica) and P. juliflora based feed rations. Coefficient of correlation was computed to assess whether there was relationship between the independent and dependent variables in the test rations. Sheep that received $T_{4}$ rations recorded the highest in vivo and in vitro nutrient digestibility (78 and 63\% respectively). Faecal output was positively correlated to DM intake $\left(r^{2}=0.88, p<0.001\right)$, in vivo $\left(r^{2}=0.87, p<0.001\right)$ and in vitro feed degradability ( $r^{2}=0.87$, $p<0.001)$. Faecal Nitrogen was negatively correlated $\left(r^{2}=-0.64, p<0.001\right)$ to these values. The high dry matter intake, in vitro and in vivo DM digestibility of Cactus (O. ficusindica) cladodes and P. juliflorabased supplementary rations authenticate their value as under-utilized drought-tolerant supplementary forages for livestock in the truncated landscapes of Kenya. Awareness creation and/or promotional campaigns of Cactus species and Prosopisjuliflorabased home-made rations (TMRs) formulation such as on-farm demonstrations, capacity building, value addition and conservation of these invasive tree species as supplementary feed for livestock during severe drought periods is recommended in this current study.
\end{abstract}

Keywords: Drought resilience, feed resources, livestock

\section{Introduction}

Supply of adequate quantity and quality of feed for livestock is a major challenge throughout the world (Koech et al2011, Nefzaoui et al 2013) This constraint of feed supply has led to low livestock productivity in most developing countries, including Kenya. However, Prosopisjuliflora has been reported to supply a cheaper feed supplement for livestock in the arid and semi-arid lands of Kenya as compared to the commercial concentrates (Koechet al2011). Prosopisjuliflora has potential to provide emergency forage feeds for livestock in pastoral communities in dry lands if knowledge on its utilization is expanded (Tewariet al2009). For instance, feeding trials in India on livestock using rations containing up to $45 \%$ of $P$. juliflora yielded $1.5 \%$ of cattle body weight with acceptable live weight gains. Collection of Prosopis speciespods is an important source of income, with earnings of up to US\$ 50 per day with collection of about 150 kg per person per day (Tewariet al2009).

On the other hand, both spiny and spineless Cactus (Opuntiaficusindica) generates a high biomass of green forageranging from 30-250 tons/ha in semi-arid areas that can sustain livestock through the driest of seasons (Nefzaoui and Mourid2009). Previous research findings by Nefzaoui et al (2013) indicated that Cactus species has the potential to significantly reduce the need for other high-energy feeds such as barley grains and maize. Unlike these conventional crops, excessive consumption of Cactus species will not cause acidosis in ruminants as a result of high levels of mucilage, which enhance salivation and avoid serious decreases in pH (Nefzaouiet al2013, Dubeux2016). Dried Cactus cladodes have been reported to partially replace maize germ in a feeding trials for weaner lambs (Ben Salem and Louhaichi2014). According to Ben Salem et al (2004), the consumption of Cactus (Opuntiaficusindica) cladodes increases the amount of omega 3 (CLA) in 
lambs and kids' meat, a factor of high importance and meets the ultimate goal of human health concern. On the other hand, lambs fed on straw supplemented with spineless Cactus (Opuntiaficusindica) and saltbush (Atriplexnumularia) grew at a rate of 80 g per day, comparable to conventional feed resources such Lucerne hay (FAO-ICARDA2017, FA0-ICARDAISHS2017).

The current study was aimed at conducting a demand-driven research to authenticate the importance of the two invasive tree species Cactus (Opuntiaficusindica) and P. juliflora), and generate a data that can be used to inform the local communities and the policy about the usefulness of these trees currently regarded as noxious weeds in Kenya. The generated data will advocate for conservation and controlling the invasiveness of these tree species by management and utilization, and not by destructive eradication. This will in turn improve the livelihoods, food and nutrition security for marginalized people living in Kenya's rangelands.

\section{Materials and Methods}

\subsection{Location of the Study}

In vitro dry matter (DM) digestibility was carried out at the University of Nairobi, Animal Production laboratory. In vivo nutrient digestibility was done at Kenya Agricultural and Livestock Research Organization (KALRO), Perkerra Research Station.

\subsection{Research Design and Treatments}

A randomized block design (RBD) was used in this study. The experimental animals (Red Maasaiweaner lambs) (at 4 months old) with an average initial live weight of $13.3 \mathrm{~kg}( \pm 2.4)$ were blocked based on their initial body weight into four blocks of four animals. The four treatment diets were randomly assigned to each animal in a block of four animals per treatment. The animals were placed in individual pens and equipped with watering and feeding troughs. Feed, which was offered at 0800 and 1600 daily, was weighed and sampled daily during the collection period and samples bulked over the 12 weeks period. A total of 288 samples were collected ( 3 samples bulked per week per animal x 6 weeks trial x 16 experimental animals), from which 103 composite sub-samples were obtained for laboratory analysis.

The treatment diets included pure rations of Cenchrusciliaris hay (used as control) and proportionally determined combinations of Prosopisjuliflorapod meal, P. julifloraleafmeal, spineless (Opuntiaficusindica) Cactus leaf meal and Cenchrusciliaris hay. Four test diets were formulated. Each animal block received one of the following four types of test diets proportions; (A) 100\% Cenchrusciliaris grass hay as basal diet (without supplementation as control, (B) $80 \%$ C. ciliaris hay $+20 \%$ wilted Cactus (Opuntiaficusindica) fodder (C) $50 \%$ C. ciliaris hay $+20 \%$ Cactus (Opuntiaficusindica) + $30 \%$ P. julifloraleaf meal (D) $50 \%$ C. ciliaris hay $+20 \%$ Cactus (O. ficusindica) fodder $+30 \%$ P. juliflorapods meal.

Ratio combinations of the test diets were based on the principle of 1:3 protein to energy ratio of inclusion level according to Leng (2005) as follows;(A) 1:0:0 (Grass forage (as control) (100\%); (B) 4:1 (Grass hay: Cactus (Opuntiaficusindica)) (80\%, 20\% respectively); (C) 5:2:3 (Grass hay: Cactus (Opuntiaficusindica): P. julifloraleaf meal (50\%, 20\%, 30\% respectively); (D) 5:2:3 (Grass hay: Cactus (Opuntiaficusindica): P. juliflorapods meal (50\%, 20\%, 30\% respectively).Feeds were offered in individual troughs, while mineral lick and water were provided separately ad libitum.

\subsection{Data Collection on Feed Intake}

Intake of the test diets (above) was determined on daily basis. In each morning, before a fresh test feed was offered, feed troughs were cleaned out and refusals weighed and recorded. The refusals were then thoroughly mixed and a subsample taken for chemical analysis and the rest discarded. The amount of test feed consumed was then determined as the difference between the amount offered and the refuse. To calculate daily feed intake, amounts of the test feeds and the control offered to and refused by each individual animal were recorded daily. Samples of feed offered and refused were collected three times per week for DM determination (dried at $105^{\circ} \mathrm{C}$ for $48 \mathrm{~h}$ ). Sub-samples of feed offered were dried at $60^{\circ} \mathrm{C}$, ground to pass through a 1-mm sieve and stored for laboratory analysis.

\subsubsection{In Vitro Dry Matter Digestibility}

In-vitro digestibility was determined according to Jouany and Thivend (1986). Four test diets were incubated separately. The test diets were; (A) 100\% Cenchrusciliaris grass hay as basal diet (as control without supplementation), (B) $80 \%$ C. ciliaris hay $+20 \%$ wilted Cactus (Opuntiaficusindica) fodder, (C) $50 \%$ C. ciliaris hay $+20 \%$ Cactus (Opuntiaficusindica) $+30 \%$ P. julifloraleaf meal, (D) 50\% C. ciliaris hay $+20 \%$ Cactus (Opuntiaficusindica) $+30 \%$ P. juliflorapods meal.

A sample of each substrate (13g DM) was incubated in duplicate in a one litre flask containing $100 \mathrm{ml}$ of rumen liquor, $100 \mathrm{ml}$ of solid rumen content, $300 \mathrm{ml}$ of artificial saliva and $187 \mathrm{mg}$ of soluble nitrogen provided as ammonium sulphate solution, and shaken in a water bath at $39^{\circ} \mathrm{C}$ for 96 hours. Rumen fluid was collected before the morning feeding from one rumen cannulated Oran steer, receiving chopped $C$. ciliaris grass hay ad libitum as basal diet and supplemented with Lucerne hay. Liquid samples of $9 \mathrm{ml}$ were taken from the flasks at the beginning of incubation $\left(t_{0}\right)$ and then after 96 hours according to the procedures described by Jouany and Thived (1986). Duplicate blank, i.e., rumen fluid without sample was included in each flask to correct for possible effect of rumen fluid on fermentation process. Dry matter residue was determined after 96 hours of digestion. 


\subsubsection{In Vivo Neutral Detergent Fibre (NDF) Digestibility}

Sixteen Red Maasaiweaner lambs (at 4 months old) with an average initial live weight of $13 \mathrm{~kg}( \pm 2.6)$ were used in the study comprising feed intake, fecal nitrogen and in vivodigestibility studies. The sheep were drenched against internal parasites before the beginning of the experiment, and housed in individual pens during the 42 days long trial. The animals were allowed 14 days adaptation period, followed by total faecal collection for 7 days. The amounts of feed offered and refused were recorded daily and samples bulked separately for each animal for the entire collection period.

Samples of feed offered, feed refused, and faeces were collected daily from each animal, and frozen pending laboratory analysis. Dry matter (DM) content of all three kinds of samples (feed offered, feed refused, and faeces) was estimated after drying the samples at $105^{\circ} \mathrm{C}$ for $24 \mathrm{~h}$. At the end of the entire collection period, feed refusals and pooled animal faecal samples and representative samples were taken for laboratory analysis. Feed offered and refused and faecal samples were dried in a forced-air oven $\left(60^{\circ} \mathrm{C}\right.$ for $\left.48 \mathrm{~h}\right)$ and ground to pass through a 1-mm sieve and stored pending chemical analysis. At the end of the feeding trial, the animals were transferred to metabolism cages for nutrient balance trials for further 14 days.

\subsection{Statistical Analysis of Feed Intake, in Vivo and in Vitro Digestibility Data}

Data were subjected to Analysis of Variance (ANOVA) using the General Linear Model (GLM) procedure of SAS (SAS 2002). Differences among treatment means were tested using least significance difference (LSD) test. Coefficient of correlation was computed to assess whether there was any relationship between the experimental diets and DMI, in vivo NDFD, faecal nitrogen, faecal output and IVDMD.

The model for data analysis was:

$Y_{i j k}=\mu+t_{i}+e_{i j k,}$

Where;

$\mathrm{Y}_{\mathrm{ijk}}=$ Response variables (DMI, in vivo NDFD, faecal nitrogen, faecal output and IVDMD), $\mu=$ Overall mean,

$\mathrm{t}_{\mathrm{i}}=$ Treatment effect $\left(\mathrm{T}_{1}, \mathrm{~T}_{2}, \mathrm{~T}_{3}, \mathrm{~T}_{4}\right)$

$\mathrm{e}_{\mathrm{ijk}}=$ Random error.

\section{Results and Discussion}

Results from this study showed that the two studied Cactus species (spiny and spineless) were not ( $>>0.05)$ different in their nutritional composition. Thus, the latter was selected for this feeding trial due to its ease of handling (spineless). The nutrient composition of the proportionally compounded experimental diets with spineless Cactus (Opuntiaficusindica), P. juliflora and C. ciliaris hay is presented in Table 1. The chemical composition of the experimental diets varied among the four formulated experimental diets.

The control diet ( $\mathrm{T}_{1}$ (Cenchurusciliaris hay) had higher dry matter (DM) content (87\%) than in the other test diets, while the lowest value of DM (70\%) was recorded in $\mathrm{T}_{4}$ (P. juliflorapods-based rations). Among the test diets, the ash content (10\%) in $\mathrm{T}_{4}$ (Prosopisjuliflora pods-based rations) was the lowest, and the highest (14\%) was in the control diets (C. ciliarishay $\left(\mathrm{T}_{1}\right)$. Crude protein (CP) content varied from $6 \%$ in the control diet $\left(\mathrm{T}_{1}\right)$ to $18.8 \%$ in $\mathrm{T}_{4}$ (P. juliflora podsbased rations). The control diets $\left(C\right.$. ciliarishay $\left(\mathrm{T}_{1}\right)$ recorded the highest neutral detergent fibre (NDF) content $(76 \%)$, whereas the lowest (66\%) was observed in $\mathrm{T}_{4}$. (P. juliflora pods-based rations (Table 1).

\subsection{In Vivo and in Vitro Nutrient Degradability Coefficients}

The treatment effect (type of ration) had ( $p<0.001)$ effect on dry matter (DM) intake of the Red Maasaiweaner lambs (Table 2). The lambs that received $P$. juliflorapods-based ration $\left(\mathrm{T}_{4}\right)$ consumed higher amounts of feed DM (863 $\mathrm{g} / \mathrm{d}$ ) as compared to those fed other rations ( $\mathrm{T}_{3}$ ( $P$. juliflora leaf meal-based ration), $\mathrm{T}_{2}$ (spineless Cactus-based rations) and the control diets ( $\mathrm{T}_{1}$ (un-supplemented $C$. liliaris hay) (Table 2). The highest faecal output (498 g/d) was observed in the lambs fed $P$. juliflorapods-based ration $\left(\mathrm{T}_{4}\right)$. Sheep that received $\mathrm{T}_{4}$ rations had also the highest in vivo and in vitro nutrient digestibility (78 and 63\% respectively).

Faecal output was positively correlated to DM intake $\left(\mathrm{r}^{2}=0.88, \mathrm{p}<0.001\right)$, in vivo $\left(\mathrm{r}^{2}=0.87, \mathrm{P}<0.001\right)$ and in vitro feed degradability $\left(r^{2}=0.87, p<0.001\right)$. However, faecal Nitrogen was negatively correlated $\left(r^{2}=-0.64, p<0.001\right)$ to these values. Prosopisjuliflorapods-based diets had $(\mathrm{P}<0.001)$ lower faecal Nitrogen excretion $(0.88 \mathrm{~g} / \mathrm{d})$ as compared to other test diets. Highest faecal Nitrogen excretion $(1.98 \mathrm{~g} / \mathrm{d})$ was recorded in the control $\left(\mathrm{T}_{1}\right.$ (C. ciliaris hay) and P. juliflora leaf meal-based diets $\left(\mathrm{T}_{3}(1.58 \mathrm{~g} / \mathrm{d})\right.$. Treatments $\mathrm{T}_{3}$ (Prosopisjuliflora leaf meal-based rations) and $\mathrm{T}_{2}$ (spineless Opuntiaficusindicabased rations) were not $(\mathrm{P}>0.05)$ different with respect to Nitrogen excretion (Table 2).

Results indicated that the in vivo digestibility of neutral detergent fibre (NDF) increased $(78 \%)(\mathrm{p}<0.001)$ in Prosopisjuliflorapods-based diets $\left(\mathrm{T}_{4}\right)$ as compared to other test diets (Table 2). However P. julifloraleaf meal-based rations $\left(\mathrm{T}_{3}\right)$ had acceptable degradability levels of above $50 \%$. The control diet $\left(\mathrm{T}_{1}\right.$ (C. liliaris hay) reported lowest degradability coefficients of below $50 \%$. The results of in vitro dry matter (DM) degradability characteristics of feeds used in the study are presented in (Table 2).

The in vitro degradability of experimental diets varied $(\mathrm{p}<0.05)$ among the treatments diets from $42 \%$ (C.ciliaris hay $\left(\mathrm{T}_{1}\right)$ to $63 \%$ for P. juliflorapods-based rations $\left(\mathrm{T}_{4}\right)$ which were degraded faster than the rest of the test diets. The study revealed that spineless Cactus (Opuntia ficus indica)-based diets $\left(\mathrm{T}_{2}\right)$ had $(\mathrm{p}<0.001)$ higher degradability (51\%) than $P$. juliflora-based leaf meal $\left(46 \% \mathrm{~T}_{3}\right)$, a factor that was not expected (Table 2). Prosopis juliflora leaf meal-based diet, being leguminouswas expected to degrade faster than the Cactus (Opuntia ficus indica)-based rations. 
The highest dry matter (DM) content $(87 \%)$ was observed in the control diets $\left(\mathrm{T}_{1}(C\right.$. ciliaris), while the lowest value $(70 \%)$ was recorded in $\mathrm{T}_{4}(P$. juliflora pods-based rations). These findings on the nutrient composition of the test diets were slightly lower than those reported by Bell et al (2016) who recorded DM content of up to $92 \%$ in diets with potential for reducing enteric methane production in ruminants. On the other hand, ash content varied among the treatment diets, with and without a protein source. Ash content is an indicator of mineral content in forages (Van Soest and Robertson1985). However, according to Ben Salem et al (2010), Ben Salem and Louhaichi (2014), high ash content of forages is also an indicator of relatively low energy in forages. The variation in ash content among treatments in this study could also be attributed to growth stages of the basal forages at harvesting (Karimi and Ungar1986). The $C$. ciliaris hay was advanced in maturity, while the spineless Cactus (Opuntiaficusindica) and P. juliflora were freshly harvested.

The crude protein (CP) of $P$. juliflora-based feed rations was within the range of 13 and 19\%, comparable to the commercial concentrate feeds available in the market (Kyuma2013). The relatively high CP values in $\mathrm{T}_{3}$ ( $P$. juliflora leaf meal-based ration) and $\mathrm{T}_{4}$ (P. juliflora pods-based ration) appeared satisfactory for animal production. This is because these CP values exceeded the minimum protein level of 7-8\% required for rumen microbial cell synthesis for maintenance (Salem and Louhaichi2014) and 12\% for milk production and growth (Kholifet al2016). This implied that these feeds can effectively be used as supplements for livestock in the rangelands as an adaptation strategy to climate change vulnerability with respect to deterioration of feed quality. However, the $\mathrm{CP}$ content of the control diet $\left(\mathrm{T}_{1}(C\right.$. ciliaris hay) was lower than the minimum levels of 7-8\% required for optimum rumen function for maintenance in ruminant animals. According to Mostafa et al (2016), forage feeds with a CP content lower than 7\% require a supplementation of nitrogen to improve their intake and digestion by the ruminants.

Cenchurusciliaris hay had the highest recorded levels of Neutral detergent fibre (NDF). Neutral detergent fibre (NDF) consists of mainly structural components (Cellulose, hemi-cellulose and lignin) which increases as the plant matures (Preston1986, Bell et al2016). These findings are also supported by Ben Salem and Louhaichi (2014) who reported significant increase in cellulose and hemi-cellulose in forages at different harvesting intervals. The NDF content of all the experimental diets were above the critical value of 60\%. According to Jafari et al (2015) and Kholif et al (2016), an NDF content in forage feeds above the critical level of 60\%decreases voluntary feed intake, feed conversion efficiency and longer retention time of feeds in the gastro-intestinal truck in livestock.

Prosopisjuliflorapods-based rations $\left(\mathrm{T}_{4}\right)$ had the highest dry matter intake. According to Kyuma (2013), the $P$. juliflorapodstogether with seeds have high CP contents ranging from 25 to 35\%. Therefore, the observed higher DM intake in animals in $\mathrm{T}_{4}$ was mainly due to the high CP content in this treatment, which could be associated with high digestibility of $P$. juliflorapods ration. Leng (2005) documented that rumen microorganisms require CP for their own cell synthesis. In this way, they multiply in number and are capable of attacking the fibrous feeds in the rumen, thereby increasing the degradability of these basal feeds. The current study implies that feed intake is not optimum when animals are fed on a basal diet such as sole hay without supplementation, and this may also limit animal production.

Generally, protein supplementation $(\mathrm{p}<0.05)$ increased faecal output. The higher faecal output of animals in $\mathrm{T}_{4}(P$. juliflora pods-based ration) could be explained by the high CP content of these feeds (188 $\mathrm{g} \mathrm{kg}^{-1} \mathrm{DM}$, as compared to $63 \mathrm{~g}$ $\mathrm{kg}^{-1} \mathrm{DM}$ in the control diet. These findings are similar to previous studies (Bengaly1996, Tolera and Sundstol2000a) who found improvement in feed intake due to protein supplementation to animals given maize stovers as basal diet. Efficient feed digestibility improves rate of feed passage in the gastro-intestinal tract, thereby creating room for more rumen filling via intake, and subsequent faecal output (Ben Salem and Louhaichi2014).

Reports from this study showed that P. juliflora pods-based rations resulted in a decrease in faecal nitrogen output.

However, these were unexpected results, where the diets with more protein supplementation is expected to produce more faecal nitrogen. The higher levels of feed intake of this test diet $\left(\mathrm{T}_{4}\right)$ can be contributed to the reported $(p<0.001)$ decrease in faecal nitrogen in this study. Additionally, the efficiency of nutrient utilization (nitrogen budget) is enhanced by optimum feed supplementation (upto 18\% CP) with a more balanced diet, thus supplying the ruminal microorganisms with nutrient for their own cell synthesis (Leng2005). In this way there is no wastage of excess nitrogen to the environments, as all will be utilized by rumen microbes for production of microbial protein. The formulated test diet $\left(\mathrm{T}_{4}\right)$ had acceptable optimum CP levels of $18 \%$, implying that there was no nutrient (nitrogen) wastage in dung, thus the reduction in the faecal nitrogen in this test ration $\left(\mathrm{T}_{4}\right)$.

These findings can also best be explained by the fact that $\mathrm{T}_{4}$ diet induced high $\mathrm{DM}$ intake concomitant with high nutrient digestibility as well as nitrogen retention, and therefore more nutrients were available for tissue deposition. This implies that diet $\mathrm{T}_{4}$ provided well balanced nutrition and resulted in absorption of ingested nutrients efficiently. These findings are supported by reports by FAO-ICARDA (2017) and FAO-ICARDA-ISHS (2017) which showed that lambs fed on straw supplemented by Cactus (Opuntiaficusindica) and saltbush (Atriplexnumularia) grew at a rate of $80 \mathrm{~g}$ per day, with a higher nitrogen balance as comparable to conventional feed resources such Rhodes grass hay without supplementation. In contrast, Tolera and Sundstol (2000b) found a negative nitrogen balance when maize stovers were fed without supplementation. In the current study, protein supplementation reduced nitrogen excretion in the dung.

A recommended maximum NDF requirement is 50-60\% (Ben Salem et al2010, Ben Salem and Louhaichi2014). The current study showed that supplementation of the basal diet of $C$. ciliariswith Cactus- $P$. juliflorapods-based rations $(\mathrm{p}<0.001)$ increased the NDF digestibility in vivo. This is in agreement with previous studies by Smith et al (1989) who found out that legumes have the highest nitrogen content, and gave the highest intake of maize stovers. This increase in NDF digestibility is best explained by the fact that nitrogen and energy supply to the rumen improves the microbial population such as fibrolitic bacteria and their associated enzymes, which degrade fibre fractions in the rumen (Leng2005). The high energy levels in the Cactus (Opuntiaficusindica) and in the P. juliflorapods (outer layer) may be 
linked to this increase in NDF digestibility in vivo. This is because microbial cells use both energy and nitrogen to synthesis their cells, without which would compromise on feed intake and digestibility.

Unexpectedly, the study revealed $(\mathrm{p}<0.001)$ higher in vitro DM digestibility in the spineless Cactus (Opuntiaficusindica)-based rations $\left(\mathrm{T}_{2}\right)$ than in $\mathrm{T}_{3}$ (P. julifloraleaf meal-based ration). This finding can be associated with condensed tannins in P. julifloraleaves (Kyuma2013). Tannins found in most browses form complexes with plant proteins which decrease their rate of degradation in the rumen. Research findings by Kaitho (1998) indicated that condensed tannins binds the proteins from digestion in the rumen and the small intestines, thus making it unavailable for absorption. However, sun drying of tanniferous foliage from the browse plants has been reported to reduce the levels of tannins in these feeds (King'oriet al2011, Koech et al2011, Jafari et al2015).

Findings on relatively low NDF digestibility in Prosopisleaf meal concur to the low in vitro DMD reported in the current study and that of $A$. nilotica reported by Rubanza et al (2003). This low in vivo and in vitro DM digestibility in Prosopis leaf meals is associated with the high levels of tannin and their interaction effects on feed digestibility (Rubanzaet al2003). The control diet $\left(\mathrm{T}_{1}\right)$ had the lowest NDF digestibility $(20 \%)$ which is far below the recommended $50 \%$ (Leng2005). In addition to the low CP in the control diet, the reported low NDF digestibility is supported by the low nutritive potential of most low-quality roughages such as hays, as in C. ciliaris observed in this study. The low digestibility of the control diet ( $\left.\mathrm{T}_{1}\right)$ could also be explained by its high proportion of fibre content in this test ration (Table 2).

Fibre fraction defines extent and rate of feed digestibility (Fonseca et al1998). Dry matter digestibility (DMD) is the portion of the dry matter in a feed that is digested by animals at a specified level of feed intake. This study showed a significant effect of energy (from spineless cactus (Opuntia ficus indica) and protein (P. juliflora) supplementation on DM digestibilty. Feed quality determines the relationship between digestibility and intake. Feed digestibility and intake are inversely related in high quality feeds (Hicks et al1990), and directly related in low quality roughages. Therefore the intake of the low quality roughage in the control diet $\left(\mathrm{T}_{1}\right)$ was mainly limited by its low digestibility. However, it was observed in the current study that the control diets contained higher levels of ash content as compared to the treatment diets. Ash content in feeds is an indicator of the available minerals in that feed.

According to Ben Salem and Louhaichi (2014), the high levels of soluble salts in the plants mean that there is a low digestible organic matter in the dry matter so that animals still need to consume high levels of DM to meet their energy requirement (Masters et al2006, Norman et al2009). Research findings by Arieli et al (1989) showed that high levels of salt can limit feed intake so animals may not be able to eat enough energy to maintain weight. Further, high salt incurs a metabolic energy cost to process and can lower the efficiency of digestible energy (DE) to metabolizable energy (ME) by up to $10 \%$ (Arieli et al1989, Masters et al2006).

\section{Conclusions}

With the observed acceptable DM intake, nitrogen retention and nutrient digestibility (in vivo and in vitro) achieved with supplementing $C$. ciliaris with Cactus (Opuntiaficusindica) and P. juliflora-based rations, high productivity of ruminant livestock in rangelands can be achieved at least cost. Therefore, management of these invasive tree species by utilization as livestock feed should be promoted but not total eradication of the plants (as requested by the local communities), which would also have adverse effects on the environment.

\section{Recommendation}

Promotional and awareness creation campaigns of Cactus species and P. juliflora-based home-made rations (TMRs) formulations through on-farm demonstrations, capacity building, value addition and conservation of these invasive tree species as supplementary feeds for livestock during severe drought periods is recommended in this current study.

\section{Acknowledgements}

The authors of this manuscript are grateful to Colorado State University (LCCCRP) for funding this research work, Egerton University for their technical support, Director General (Kenya Agricultural and Livestock Research Organization (KALRO) for providing good working environment for research, and all the pastoral communities in the study counties for their cooperation during this study.

\begin{tabular}{|c|c|c|c|c|}
\hline Treatments & DM & CP & NDF & Ash \\
\hline TRT $_{1}$ (C 100) (control) & 87.3 & 6.3 & 75.6 & 13.9 \\
\hline $\mathrm{TRT}_{2}(\mathrm{C} 80, \mathrm{CT} 20)$ & 80 & 8.2 & 73.8 & 13.3 \\
\hline $\mathrm{TRT}_{3}(\mathrm{C} 50, \mathrm{CT} 20, \mathrm{PL} 30)$ & 72 & 12.5 & 70.4 & 13 \\
\hline $\mathrm{TRT}_{4}(\mathrm{C} 50, \mathrm{CT} 20,30 \mathrm{PP})$ & 70 & 18.8 & 66.3 & 9.6 \\
\hline \multicolumn{5}{|c|}{$\begin{array}{l}\text { Abbreviations: C: Cenchurusciliarishay, CT: Spineless Cactus, PL: Prosopisjuliflora } \\
\text { leaf meal, PP: Prosopisjuliflora pods meal DM: Dry matter, CP: Crude protein, NDF: } \\
\text { Neutral detergent fibre }\end{array}$} \\
\hline \multicolumn{5}{|c|}{$\mathrm{T}_{1}$ : C. ciliaris (100\% (control), $\mathrm{T}_{2}$ : C. ciliaris $(80 \%)+$ Spineless cactus $(20 \%)}$, \\
\hline \multirow{2}{*}{\multicolumn{5}{|c|}{$\begin{array}{l}\mathrm{T}_{3}:(\text { C. ciliaris }(50 \%)+\text { Spineless cactus }(20 \%)+P \text {. juliflora leaf meal }(30 \%), \\
\mathrm{T}_{4}:(\text { C. ciliaris }(50 \%)+\text { Spineless cactus }(20 \%)+P \text {. juliflora pods meal }(30 \%)\end{array}$}} \\
\hline & & & & \\
\hline
\end{tabular}




\begin{tabular}{|c|c|c|c|c|c|c|c|}
\hline & \multicolumn{4}{|c|}{ Treatments } & \multirow[b]{2}{*}{ SEM } & \multirow[b]{2}{*}{ LSD } & \multirow[b]{2}{*}{ p-value ${ }_{(0.05)}$} \\
\hline Variable & $\mathbf{T}_{1}$ & $\mathbf{T}_{2}$ & $\mathbf{T}_{3}$ & $\mathbf{T}_{4}$ & & & \\
\hline DMI (g/d) & $402^{c}$ & $553^{b}$ & $684^{b}$ & $863^{a}$ & 42.5 & 135.8 & $0.001^{* * *}$ \\
\hline In vivo NDFD (\%) & $20.0^{\mathrm{d}}$ & $47.0^{c}$ & $63.0^{\mathrm{b}}$ & $78^{a}$ & 2.49 & 7.98 & $0.001^{* * *}$ \\
\hline Faecal-N (g/d) & $1.98^{\mathrm{a}}$ & $1.22^{\mathrm{bc}}$ & $1.58^{\mathrm{ab}}$ & $0.88^{c}$ & 0.13 & 0.43 & $0.001^{* * *}$ \\
\hline $\begin{array}{l}\text { Faecal output } \\
(\mathrm{g} / \mathrm{d})\end{array}$ & $163^{c}$ & $266^{\mathrm{b}}$ & $331^{\mathrm{b}}$ & $498^{a}$ & 23.8 & 76 & $0.001^{* * *}$ \\
\hline IVDMD (\%) & $42^{d}$ & $51^{b}$ & $46^{c}$ & $63^{a}$ & 0.19 & 0.4 & $0.001^{* * *}$ \\
\hline \multicolumn{8}{|c|}{ abcMeans with different superscript letters along the same row differ significantly $(\mathrm{p}<0.05)$. } \\
\hline \multirow{2}{*}{\multicolumn{8}{|c|}{$\begin{array}{l}\text { Abbreviations:DMI: Dry matter intake, In vivo NDF-D: In vivo Neutral detergent fibre digestibility, } \\
\text { Faecal-N: Faecal Nitrogen, IVDMD: In vitro dry matter digestibility, SEM: Standard error of means, }\end{array}$}} \\
\hline & & & & & & & \\
\hline \multicolumn{8}{|c|}{ LSD; LSD; Least significant differences of mean (5\% level) } \\
\hline \multicolumn{8}{|c|}{$\begin{array}{c}\mathrm{T}_{1}: \text { C. ciliaris }\left(100 \% \text { (control), } \mathrm{T}_{2}: \text { C. ciliaris }(80 \%)+\text { Spineless cactus }(20 \%), \mathrm{T}_{3}:(\text { C. ciliaris }(50 \%)\right. \\
+ \text { Spineless cactus }(20 \%)+\text { Prosopisjuliflora leaf meal }(30 \%), \mathrm{T}_{4}:(\text { C. ciliaris }(50 \%)+\text { Spineless cactus } \\
(20 \%)+\text { Prosopisjuliflora pods meal }(30 \%)\end{array}$} \\
\hline
\end{tabular}

\section{References}

i. Arieli, A., Naim, E., Benjamin, R. W., and Pasternak. D. (1989). The effect of feeding saltbush and sodium chloride on energy metabolism in sheep. Journal of Animal Production, 49, 451-457.

ii. Bell, M., Eckard, R., Moate, P. J., and Yan, T. (2016). Modelling the effect of diet composition on enteric methane emissions across sheep, beef and dairy cows. Animals, 6, 54-60.

iii. Ben Salem, H., and Louhaichi, M. (2014). Promoting cactus as an alternative and sustainable livestock feed. ICARDA's publication factsheet.

iv. Ben Salem, H., Norman, H. C., Nefzaoui, A., Mayberry, D. E., Pearce, K. L, and Revell, D. K. (2010). Potential use of oldman saltbush (Atriplexnummularia) in sheep and goat feeding. Small Ruminants Research, 91, 13-28.

v. Bengaly, K. (1996). Effect on intake and digestion of maize stover when supplemented with urea and/or lablab (Lablab purpureus) hay and given to native cattle in Southern Mali (Master's Thesis). University of Aberdeen.

vi. Dubeux, J. C. (2016). Cactus: A crop for the dry areas. Broadening Horizons pp1-2April 2016. Available at: http://www.feedipedia.org/ content/cactus-crop-dry areas.

vii. FAOICARDA. (2017). Crop ecology, cultivation and uses of cactus pear. Eds. InglesP, MondragonC, NefzaouiAand Saenz C. pp225FAORomeItaly. http://www.fao.org/3/a-i7012e.pdf.

viii. FAOICARDA-ISHS. (2017). CAM crops for a hotter and drier world: book of abstracts and symposium program. IX International Congress on Cactus Pear and CochinealUniv. de Chile Ed. FAO-ICARDA Int. Coop. Network CACTUSNET, Coquimbo, Chile, March 26-30, 2017. http://www.feedipedia.org/node/23236.

ix. Fonseca, A. J., Dias-da-Silva, A. A., and Orscov, E. R. (1998). In sacco degradation characteristics as predictors of digestibility and voluntary intake of roughages by mature ewes. Journal of Animal Feed Science and Technology, 72, 205-219.

X. Hicks, R. B., Owen, F. N., Gill, D. R., Martin, J. J., and Strasia, C. A. (1990). Effects of controlled feed intake on performance and carcass characteristics of feedlot steers and heifers. Journal of Animal Science, 68, 233-244. http://resources.ciheam.org/om/pdf/.

xi. Jafari, S., Alizadeh, A., Imni, A., Meng, G. Y., Rajion, M. A., and Ebrahimi, M. (2015)In situ degradation of almond (Prunusdulcis L.) hulls, a potential feed material for ruminants. Journal of Veterinary and Animal Science, 39, 676-681.

xii. Jouany, J., and Thivend, F. (1986). In vitro effects of evoparcin on protein degradability and rumen fermentation. Journal of Animal Feed Science and Technology, 15, 215-229.

xiii. Kaitho, R. J., Umunna, N. N., Nsahlai, I. V., Tamminga, S., and Van Bruchem, V. (1998). Utilization of browse supplements with varying tannin levels by Ethiopian Menz sheep 2. Nitrogen metabolism. Agroforestry Systems, 39, 161-173.

xiv. Karimi, S. H., and Ungar, A. I. (1986). Oxalate and inorganic ion concentration in Atriplex species in response to salinity, light level and aeration. Botanical Gazzet,147, 65-70.

xv. Kholif, A. E., Morsy, T. A., Gouda, G. A., Anele, U. Y., and Galyean, M. L. (2016). Effect of feeding diets with processed Moringaoleifera meal as protein source in lactating Anglo-Nubian goats. Journal of Animal Feed Science and Technology. doi:10.1016/j.anifeedsci. 2016.04.012.

xvi. King'ori, A. M., Odero-Waitituh, J. A., and Guliye, A. Y. (2011). Mathenge (Prosopisjuliflora): An underutilized livestock feed resource in Kenya. Journal of Animal Science, 5, 43-51.

xvii. Koech, K., Kinuthia, R., and Wahome, R. (2011). Use of dry land tree species (Prosopisjuliflora) seed pods as supplement feed for goats in the arid and semi-arid lands of Kenya. Journal of Arid Environment, 5, 66-73.

xviii. Kyuma, R. (2013). Prosopisspp utilization as animal feedtrials in Garissa, Kenya Wathajir Group Farm. Community Prosopis utilization pilot project. Proceeding of Tanzania Society of Animal Production Annual Scientific Conference held on $22^{\text {nd }}-25^{\text {th }}$ October 2013, Olasit Garden, Arusha, Tanzania. 
xix. Leng, R. A. (2005). Metabolizable protein requirements of ruminants fed roughage diets. In: Rowlinson P, WachirapokornP, Pakdee P and Wanapat M. Proceedings of the International Conference on Livestock-Crop Systems to meet the challenges of globalisation. KhonKaen, Thailand, 1, 330-347.

xx. Masters, D. G., Edwards, N., Silence, A., Avery, A., Revell, D., Friend, M., Sanford, P., Saul, G., Beverly, C., and Young, J. (2006). The role of livestock in the management of dry land salinity. Australian Journal of Experimental Agriculture, 46, 733-741.

xxi. Mostafa, Y. E., Hassan, K., Mohammad, S. D., Ahmed, E. K., Mona, M., Elghandour, Y., Saul, R. H., Odongo, E. N., and Abdelfattah, Z. M. (2017). The chemical compositionandin vitro digestibility evaluation of almond tree (Prunusdulcis) leaves versus hulls and green versus dry leaves as feed for ruminants. Agroforestry Systems, 91, 773-780.

xxii. Nefzaoui, A., Louhaichi, M., and Ben Salem, H. (2013). Cactus as a tool to mitigate drought and to combat desertification. Journal of Arid Land Studies, 24, 121-124.

xxiii. Norman, H. C., Revell, D. K., Mayberry, D. E., Rintoul, A. J., Wilmot, M. G., and Masters, D. G. (2009). Comparison of in vivo organic matter digestibility of native Australian shrubs to in vitro and in sacco predictions. Small Ruminant Research, 1, 1-23.

xxiv. Preston, T. R. (1986). Better utilization of crop residues and by-products in animal feeding: research guidelines 2: A practical manual for research workers. FAO Animal Production and Health Paper 50/2. Rome Italy. Production. In D. R. Lee., C. B. Barrett (Eds.), Tradeoffs or synergies? Agricultural intensification, economic development and the environment. CABI International, Wallingford, UK (pp. 345-364).

xxv. Rubanza, C. D., Shem, M. N., Otsyina, R., Ichinohe, T., and Fujihara, T. (2003). Nutritive evaluation of some browse tree legume forages native to semi-arid areas in western Tanzania. Asian-Australian Journal of Animal Science, 16, 1429-1437.

xxvi. Smith, T., Manyuchi, B., and Mikairi, S. (1989). Legume supplementation of maize stover. In B. H. Dzowela., A. N. Said., A. Wendem-Agenehu., and J A. Kategile(Eds.), Utilization of research results on forage and agricultural pyproductmaterials as animal feed resources in Africa, (pp. 303-320). ILCA, Addis Ababa, Ethiopia.

xxvii. Tewari, J., Harris, P., Harsh, L., Cadoret, K., and Pasiecznik, N. (2000). Managing Prosopisjuliflora: A technical manual. CAZRIJodhpur and HDRACoventryUK96p.

xxviii. Tolera, A., and Sundstøl, F. (2000a). Supplementation of graded levels of Desmodium intortum hay to sheep feeding on maize stover harvested at three stage of maturity 1: Feed intake, digestibility and body weight change. Animal Feed Science and Technology, 85, 239-257.

xxix. Tolera, A., and Sundstøl, F. (2000b). Supplementation of graded levels of Desmodium intortum hay to sheep feeding on maize stover harvested at three stage of maturity. 2. Rumen fermentation and nitrogen metabolism. Animal Feed Science and Technology, 87, 215-229.

xxx. Van Soest, P. J., and Robertson, J. B. (1985). Systems of analysis for evaluating fibrous feeds. In W. Pidgen., W. Balch.,andGraham M (Eds.), A Laboratory Manual for Animal Science. Cornell University, Ithaca, NY.(pp. 61-73). 